\title{
PERBANDINGAN INDEKS KEANEKARAGAMAN SERANGGA DI WILAYAH EKOSISTEM HUTAN PENYANGGA TAMAN NASIONAL GUNUNG LEUSER BUKIT LAWANG
}

Balai Diklat Keagamaan Medan JI. TB. Simatupang No. 122 Medan Telp. (061)8456256

E-mail: narnowibdkmdn@gmail.com Naskah diterima: 20 November 2021 Naskah Direvisi: 21-30 November 2021 Naskah disetujui: 03 Desember 2021 Website Jurnal: http://apicbdkmedan.kemenag.go.id.

\author{
Gunarno
}

\begin{abstract}
ABSTRAK
Penelitian ini bertujuan untuk mengetahui indeks keanekaragaman dan perbandingan indeks keanekaragaman serangga di Taman Nasional Gunung Leuser Bukit Lawang pada wilayah ekosistem Penyangga. Metode penelitian menggunakan pendekatan deskriptif kuantitatif. Populasi dalam penelitian ini adalah seluruh hewan yang tergolong serangga (Insecta). Dengan sampel yang digunakan adalah serangga di daerah hutan penyangga dengan 3 titik (jalur) tegakan. Teknik analisis data menggunakan Indeks keanekaragaman dari Shannon-Wiener. Hasil penelitian menunjukkan bahwa serangga dengan indeks nilai penting (INP) paling tinggi dari ketiga jalur (Tanpa tegakan, tegakan karet dan tegakan cokelat) adalah Macrotermes gilvus yaitu 91,71 (tegakan pohon karet), 87,54 (tegakan pohon cokelat) dan 57,42 (tanpa tegakan). Indeks keanekaragaman serangga $H^{\prime}$ yang menggunakan (Indeks Shannon-Wiener) dari ketiga jalur tanpa tegakan (-2), tegakan karet (-1) dan tegakan cokelat (-1) adalah "rendah". Rendahnya indeks keanekaragaman hutan penyangga ini karena hutan penyangga di Bukit Lawang merupakan hutan homogen.
\end{abstract}

Kata kunci: perbandingan, indek keanekaragaman, serangga

\begin{abstract}
This study aims to determine the diversity index and the comparison of insect diversity index in Gunung Leuser Bukit Lawang National Park in the Buffer ecosystem area. The research method uses a quantitative descriptive approach. The population in this study were all animals classified as insects (Insecta). The samples used were insects in the buffer forest area with 3 standpoints (lines). The data analysis technique uses the Shannon-Wiener diversity index. The results showed that the insect with the highest significance index (INP) from the three lines (without stands, rubber stands, and cocoa stands) was Macrotermes gilvus, namely 91.71 (rubber tree stands), 87.54 (cocoa tree stands), and 57. 42 (without stands). The insect diversity index $\mathrm{H}^{\prime}$ using (Shannon-Wiener Index) from the three lines without stands (-2), rubber stands (-1), and brown stands (-1) were "low". The low diversity index of the buffer forest is because the buffer forest in Bukit Lawang is a homogeneous forest.
\end{abstract}

Keywords: comparison, diversity index, insects

\section{PENDAHULUAN}

Berdasarkan data Wilayah Ekologi (Ecoregion) dan secara administratif kabupaten Langkat, Sumatera Utara. Kawasan Taman Nasional Gunung Leuser (TNGL) membentang sepanjang 1292 
kilometer berada dalam Provinsi Aceh dan Sumatera Utara, antara 98-30 derajat BT dan 2.55-4.05 derajat LU. Fokus program Pride Campaign adalah kawasan TNGL wilayah SPTN VI Besitang-Langkat-Sumatera Utara.

Bukit Lawang merupakan salah satu daerah wisata yang terletak di Kecamatan Bahorok, Kabupaten Langkat. Bukit lawang yang terkenal dengan panorama dan keindahan alam yang banyak menarik wisatawan baik lokal maupun wisatawan mancanegara, dan juga merupakan kawasan konservatif dari hutan dan hewan langka di dalam Taman Nasional Gunung Leuser (TNGL). Hutan Leuser kaya akan kehidupan flora dan fauna, dan kawasan ini juga kerap dinobatkan sebagai paru-paru dunia. Namun dari data yang ada, terlihat bahwa 22 persen kawasan hutan dirambah oleh oknum-oknum tertentu yang memanfaatkan hutan untuk keuntungan ekonomis semata, namun tidak memperdulikan akibat yang terjadi di masa depan. Salah satu akibat yang ditimbulkan bila melakukan eksploitasi terhadap hutan adalah seperti terjadinya banjir bandang yang terjadi pada November 2003 lalu.

Aktivitas masyarakat yang tinggi di wilayah Bukit Lawang khususnya di kawasan hutan penyangga seperti penebangan hutan, pemanfaatan hutan sebagai tempat pemukiman mengakibatkan perubahan lingkungan yang berdampak terhadap keanekaragaman dan penyebaran makhluk hidup khususnya serangga. Keanekargaman makhluk hidup sangat penting bagi kelangsungan dan kelestarian makhluk hidup. Suatu kelompok makhluk hidup yang memiliki kelestarian tinggi, terdapat keanekaragaman yang tinggi.
Sebaliknya makhluk hidup yang memiliki tingkat kelestarian rendah, terdapat keanekaragaman rendah dan terancam punah. Keanekaragaman makhluk hidup bersifat tidak tetap atau tidak stabil. Hal ini disebabkan oleh campur tangan manusia terhadap lingkungan yang dapat mempengaruhi keanekaragaman. Penurunan keanekaragaman makhluk hidup dapat terjadi secara alami dan campur tangan manusia khususnya di kawasan hutan penyangga Bukit Lawang.

Serangga adalah salah satu anggota kerajaan binatang yang mempunyai jumlah anggota yang terbesar. Hampir lebih dari $72 \%$ anggota binatang termasuk kedalam golongan serangga. Serangga telah hidup di bumi kira-kira 350 juta tahun, dibandingkan dengan manusia yang kurang dari dua juta tahun. Selama kurun ini mereka telah mengalami perubahan evolusi dalam beberapa hal dan menyesuaikan kehidupan pada hampir setiap tipe habitat. Serangga dapat berperan sebagai pemakan tumbuhan (serangga jenis ini yang terbanyak anggotanya). Sebagai parasitoid (hidup secara parasit pada serangga lain), sebagai predator (pemangsa), sebagai pemakan bangkai, sebagai penyerbuk (misalnya tawon dan lebah) dan sebagai penular (vektor) bibit penyakit tertentu.

$$
\text { Penelitian tentang indeks }
$$
keanekaragaman serangga bertujuan untuk mengetahui indeks keanekaragaman serangga di daerah Bukit Lawang khususnya di kawasan hutan penyangga. Hasil penelitian ini juga dapat menunjukkan bagaimana perbandingan indeks keanekaragaman serangga di daerah tersebut. Hasil yang didapat nantinya dapat mengindikasikan bagaimana penyebararan keragaman suatu makhluk hidup 
khususnya serangga di kawan hutan Bukit Lawang. Penelitian ini juga diharapkan dapat memberi pengetahuan kepada masyarakat tentang pelestarian lingkungan di daerah Bukit Lawang. Khususnya yang berdampak terhadap pelestarian populasi serangga. Jadi berdasarkan uraian di atas peneliti akan meneliti tentang "Perbandingan Indeks Keanekaragamn Serangga di Wilayah Ekosistem Hutan Penyangga Bukit Lawang".

Berdasarkan latar belakang masalah di atas maka yang menjadi rumusan masalah pada penelitian ini adalah: 1) bagaimana indeks keanekaragaman serangga di kawasan Hutan Penyangga Bukit Lawang?; 2) bagaimana perbandingan indeks keanekaragaman serangga di kawasan Hutan Penyangga Bukit Lawang? Tujuan dilakukannya penelitian ini adalah untuk mengetahui: 1) indeks keanekaragaman serangga indeks keanekaragaman serangga di kawasan Hutan Penyangga Bukit Lawang; 2) perbandingan indeks keanekaragaman serangga indeks keanekaragaman serangga di kawasan Hutan Penyangga Bukit Lawang.

Serangga (Insekta) digolongkan dalam phylum Arthropoda. Serangga sebagai salah satu golongan hewan penghuni terbesar dimuka bumi. Diperkirakan bahwa jumlah seluruh serangga menduduki tiga perempat bagian dari semua hewan yang ada, dan dari jumlah tersebut 750.000 spesies telah berhasil diketahui dan diberi nama. Jumlah tersebut merupakan lebih kurang 80\% dari phylumnya sendiri (Sunjaya, 1994).

Serangga merupakan kelompok hewan yang dominan di muka bumi dengan jumlah spesies hamper $80 \%$ dari jumlah total hewan hewan di bumi. Sebagian besar spesies serangga memiliki manfaat bagi manusia. Sebanyak 1.413 .000 spesies telah berhasil diidentifikasi dan dikenal, lebih dari 7.000 spesies baru ditemukan hamper setiap tahun. Serangga juga sangat berperan dalam menjaga daur hidup rantai dan jaringan-jaring makanan di suatu ekosistem. Serangga hidup kurang lebih 350 juta tahun yang lalu dan menyebar ke seluruh tempat untuk beradaptasi dan berkembang biak, keberadaan serangga bagi manusia dapat memberikan keuntungan dan kerugian (Zulkarnain, 2013).

Umumnya tubuh serangga terbagi atas 3 ruas utama tubuh (caput, torak dan abdomen). Morfologi serangga pada bagian kepala terdapat mulut, antena, mata majemuk (faset) dan tunggal (ocelli). Pada bagian abdomen dapat dilihat membaran timpani dan spirakel. Sedangkan di bagian abdomen dapat dilihat membrane timpani, spirakel dan alat kelamin. (Arnest dkk, 1981).

Serangga menyusun sekitar 64\% dari total spesies flora dan fauna yang diperkirakan ada di bumi ini (Grombridge, 1992). Dengan jumlah spesies dan individu yang bergitu besar maka serangga memegang peranan yang sangat penting dalam suatu ekosisetem. Diantaranya pern tersebut adalah: herbivora, predasi, parasitisme, dekomposisi, penyerbukan dan sebagainya (Speigh et.al, 1999).

Serangga juga telah digunakan sebagai indikator. Penggunaan bioindikator akhir ini semakin penting dengan tujuan utama untuk menggambarkan adanya keterkaitan dengan kondisi faktor biotik dan abiotik lingkungan.

Hutan Penyangga, yaitu kawasan hutan yang menjadi wilayah peralihan 
antara hutan lindung dan hutan produksi.

Kawasan ini hendaknya dijaga kelestariannya, jangan sampai para pengelola hutan produksi terus mengeksploitasi sumber daya hutan sampai ke wilayah hutan lindung. Daerah penyangga adalah wilayah yang berada diluar kawasan suaka alam maupun kawasan pelestarian alam baik sebagai kawasan hutan lainnya, tanah negara bebas maupun tanah yang dibebani hak yang diperlukan dan mampu menjaga keutuhan kawasan suaka alam dan kawasan pelestarian alam.

Pengertian hutan penyangga adalah kawasan hutan yang menjadi wilayah peralihan antara hutan lindung dan hutan produksi. Eko Sujatmiko (2014). Kondisi lingkungan yang berbeda di penyangga pada wilayah tanpa tegakan dan tegakan karet mampu memberikan pengaruh terhadap kehidupan organisme, baik dari kehidupan tumbuhan maupun hewan mulai dari hewan invertebrate dan vertebrata.

Kondisi lingkungan yang berbeda di daerah penyangga antara wilayah tanpa tegakan dan tegakan cokelat mampu memberikan pengaruh terhadap kehidupan organisme, baik dari kehidupan tumbuhan maupun hewan mulai dari hewan invertebrate dan vertebrata.

Berdasarkan kajian teoritis dan kerangka berfikir maka hipotesis yang diajukan dalam penelitian ini sebagai berikut: $\mathrm{H}_{\mathrm{o}} 1=$ tidak terdapat perbandingan yang signifikan indeks keanekaragaman serangga di daerah tanpa tegakan, tegakan karet dan tegakan cokelat. $\mathrm{H}_{\mathrm{a}} 1$ : terdapat perbandingan yang signifikan indeks keanekaragaman serangga di daerah tanpa tegakan, tegakan karet dan tegakan cokelat.

\section{METODOLOGI PENELITIAN}

Penelitian ini termasuk dalam jenis penelitian deskriptif. Penelitian deskriptif adalah salah satu jenis penelitian yang tujuannya untuk menyajikan gambaran lengkap mengenai setting sosial atau dimaksudkan untuk eksplorasi dan klarifikasi mengenai suatu fenomena atau kenyataan sosial, dengan jalan mendeskripsikan sejumlah variabel yang berkenaan dengan masalah dan unit yang diteliti antara fenomena yang diuji. Pendekatan penelitian dalam penelitian ini menggunakan pendekatan kuantitatif.

Penelitian ini dilakukan pada hari Jumat sampai dengan hari Sabtu, tanggal 16-17 Oktober 2020. Penelitian ini dilaksanakan di daerah Kawasan Hutan Penyangga - Bukit Lawang Sumatera Utara. Populasi dalam penelitian ini adalah seluruh hewan yang tergolong serangga (Insekta). Dalam penelitian ini pengambilan sampel digunakan adalah serangga di daerah tanpa tegakan, serangga di daerah tegakan karet dan serangga di daerah tegakan cokelat.

Pengambilan data dengan menggunakan metode eksploratif yaitu pengamatan atau pengambilan sampel langsung dari lokasi pengamatan, dimana lokasi pengamatan atau pengambilan sampel terletak di Kawasan Hutan Penyangga. Dalam pengambilan sampel kawasan hutan penyangga tersebut dibagi menjadi 3 Jalur sebagai perwakilan dari seluruh kawasan hutan penyangga. Masingmasing jalur dibagi menjadi 3 petak contoh berukuran $4 \times 4 \mathrm{~m}^{2}$. Pengambilan sampel serangga dilakukan dengan metode perangkap jebak yang terdiri dari Fit Fall Trap, Light Trap dan Sweepnet.

Parameter yang diukur dalam penelitian ini adalah Kerapatan, Frekuensi, 
dan Indeks Nilai Penting (INP), Indeks Keanekaragaman $\left(\mathrm{H}^{\prime}\right)$ dari ShannonWienner. Data yang didapatkan dianalisis Kerapatan (K), Frekuensi (F), dan Indeks Nilai Penting (INP) untuk dapat menentukan Indeks keanekaragaman dari Shannon-Wiener $\left(H^{1}\right)$.

Frekuensi $(F)=\frac{\text { Jumlah ditemukan suatu spesies }}{\text { Jumlah Seluruh penangkapan }}$

Frekuensi relative $(F R)=$

Nilai F M suatu jenis serangga setiap penangkapan Total jumlah seluruh serangga setiap penangkapan $x 100 \%$

Kerapatan Mutlak $(K M)=$

Jumlah individu jenis yang tertangkap Jumlah penangkapan

\section{Kerapatan Relatif $(K R)=$} $\frac{\text { Jumlah individu suatu jenis dalam penangkapan }}{\text { Total individu dalam setiap penangkapan }} \times 100 \%$

Indeks keanekaragaman dari ShannonWiener

$$
H^{\prime}=\sum_{i=1}^{S}(p i)(\ln p i)
$$

ni = jumlah individu jenis ke-i

$\mathrm{N}=$ jumlah total individu semua jenis

Kreteria Indeks keanekaragaman $\left(\mathrm{H}^{\prime}\right)$ :
$\mathrm{H}=<1 \rightarrow$ (kondisi lingkungan tidak stabil)

$\mathrm{H}=1-3 \rightarrow$ (kondisi lingkungan sedang)

$\mathrm{H}=>3 \rightarrow$ (kondisi lingkungan stabil)

\section{HASIL DAN PEMBAHASAN}

Penelitian ini dilakukan di kawasan hutan penyangga Bukit Lawang di Taman Nasional Gunung Leuser pada tanggal 1617 Oktober 2020. Pengambilan sampel dilakukan dengan mengambil dan mengumpulkan serangga yang tertangkap pada masing-masing titik sampel perangkap yang telah ditentukan. Adapun titik pengambilan sampel meliputi 3 jalur pada kawasan hutan penyangga yang masing-masing terdiri dari 3 petak contoh berukuran $16 \mathrm{~m}^{2}$. Penangkapan serangga dilakukan dengan menggunakan berbagai perangkap yaitu Fit Fall Trap, Sweep Net dan Light Trap.

Jalur I pada pengambilan sampel serangga terletak di halaman rumah warga. Dari data yang diperoleh pada jalur I didapat 12 jenis serangga. Pengamatan pada hasil penangkapan serangga yang tertangkap dapat dilihat pada tabel 1 berikut.

Tabel 1. Jumlah Serangga yang Tertangkap pada Jalur I Tanpa Tegakan dengan Indeks Nilai Penting(

\begin{tabular}{|c|c|c|c|c|c|c|c|c|c|c|}
\hline \multirow{2}{*}{ No } & \multirow{2}{*}{ Nama Insekta } & \multicolumn{3}{|c|}{ Jumlah } & \multirow{2}{*}{$\begin{array}{c}\text { Jlh } \\
\text { Total }\end{array}$} & \multirow[t]{2}{*}{ KM } & \multirow[t]{2}{*}{ KR (\%) } & \multirow[t]{2}{*}{ FM } & \multirow[t]{2}{*}{ FR (\%) } & \multirow[t]{2}{*}{ INP } \\
\hline & & 1 & 2 & 3 & & & & & & \\
\hline 1 & Macrotermes gilvus & 75 & 30 & 7 & 112 & 2,33 & 42,42 & 1,00 & 15,00 & 57,42 \\
\hline 2 & Semut hitam kecil & 15 & 0 & 0 & 15 & 0,31 & 5,68 & 0,33 & 5,00 & 10,68 \\
\hline 3 & Semut Hitam besar & 1 & 0 & 0 & 1 & 0,02 & 0,38 & 0,33 & 5,00 & 5,38 \\
\hline 4 & Celes variabilis & 0 & 0 & 1 & 1 & 0,02 & 0,38 & 0,33 & 5,00 & 5,38 \\
\hline 5 & Anophius nigerninus & 2 & 16 & 0 & 18 & 0,38 & 6,82 & 0,67 & 10,00 & 16,82 \\
\hline 6 & Semut Merah Bersayap & 0 & 2 & 25 & 27 & 0,56 & 10,23 & 0,67 & 10,00 & 20,23 \\
\hline 7 & Formica $s p$ & 0 & 34 & 0 & 34 & 0,71 & 12,88 & 0,33 & 5,00 & 17,88 \\
\hline 8 & Gryllus assimilis & 16 & 6 & 13 & 35 & 0,73 & 13,26 & 1,00 & 15,00 & 28,26 \\
\hline 9 & Melanoplus fermurruburm & 4 & 0 & 2 & 6 & 0,13 & 2,27 & 0,67 & 10,00 & 12,27 \\
\hline 10 & Belalang kayu & 10 & 0 & 3 & 13 & 0,27 & 4,92 & 0,67 & 10,00 & 14,92 \\
\hline
\end{tabular}




\begin{tabular}{rlccccccccc}
\hline 11 & Olibrus liquidus & 0 & 0 & 1 & 1 & 0,02 & 0,38 & 0,33 & 5,00 & 5,38 \\
\hline 12 & Blaberidae sp & 0 & 0 & 1 & 1 & 0,02 & 0,38 & 0,33 & 5,00 & 5,38 \\
\hline Jumlah & 123 & 88 & 53 & 264 & 5,50 & 100 & 6,67 & 100 & 200 \\
\hline
\end{tabular}

Dari data tabel 1 pada Jalur I tanpa tegakan di atas, diperolehlah 12 jenis serangga dari perlakuan mulai dari sweepnet (pagi dan sore), fit fall trap dan light trap dengan jumlah individu sebanyak 264. Dari tabel diatas dapat diketahui bahwa nilai Kerapatan Mutlak (KM) tertinggi adalah kelompok Laron (Macrotermes gilvus) sebanyak 2,33 dengan nilai Kerapatan Relatif (KR) sebesar 42,42\% sedangkan Kerapatan Mutlat (KM) terendah adalah kelompok semut hitam besar, belalang kerdil hitam, Olibrus sp.dan Blaberidae sp. sebanyak 0,02 dengan Kerapatan Relatif (KR) sebesar 0,38\% . Nilai Frekuensi Mutlak (FM) tertinggi adalah kelompok Laron dan
Jangkrik yaitu sebanyak 1 dengan Frekuensi Relatif (FR) sebesar 15\%. Sedangkan Nilai Frekuensi Mutlak (FM) terendah diperoleh oleh kelompok semut hitam besar, belalang kerdil hitam, Olibrus sp.dan Blaberidae sp. sebanyak 0,33 dengan Frekuensi Relatif (FR) sebesar 5\%. Adapun Indeks Nilai Penting (INP) tertinggi diperoleh kelompok Laron dengan INP sebesar 57,42 sedangkan Indeks Nilai Penting (INP) terendah adalah kelompok semut hitam besar, belalang kerdil hitam, Olibrus sp.dan Blaberidae sp. sebesar 5,38. Untuk Indeks Nilai Penting (INP) yang diperoleh pada masing-masing kelompok serangga dapat dilihat pada gambar 1, berikut:

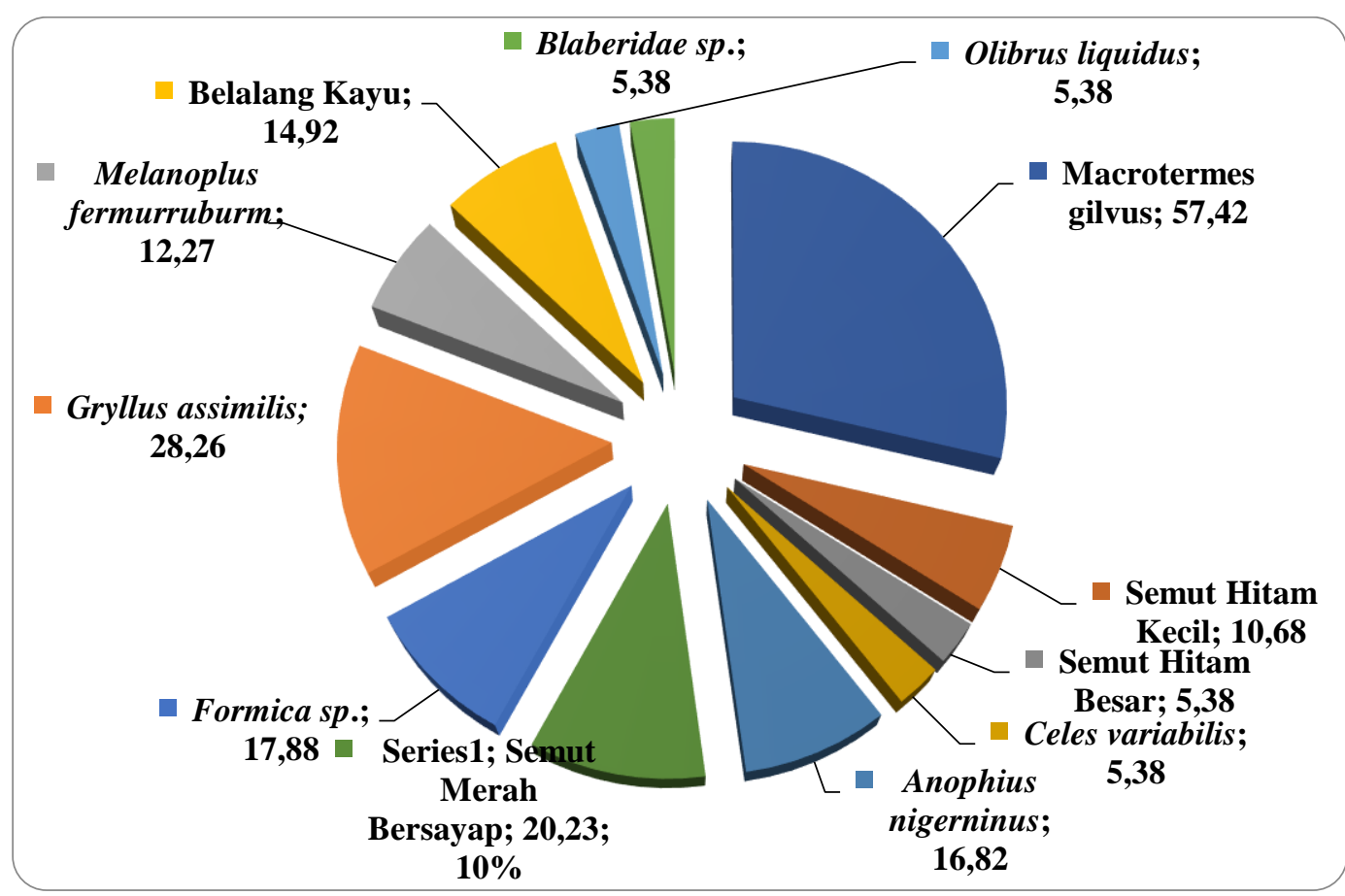

Gambar 1. Indeks Nilai Penting (INP) masing-masing serangga Jalur I Tanpa Tegakan

Jalur II merupakan tempat pengambilan data yang didominasi tegakan karet, didapat 16 jenis serangga, sehingga diperoleh indeks nilai penting (INP) data pada table 2. berikut. 
Tabel 2. Jumlah Serangga yang Tertangkap Indeks Nilai Penting (INP) Jalur 2 Tegakan Karet

No Nama Insekta

Jumlah

$\begin{array}{lllll}\text { Jlh Total } & \mathrm{KM} & \mathrm{KR} \% & \mathrm{FM} & \mathrm{FR}(\%)\end{array}$

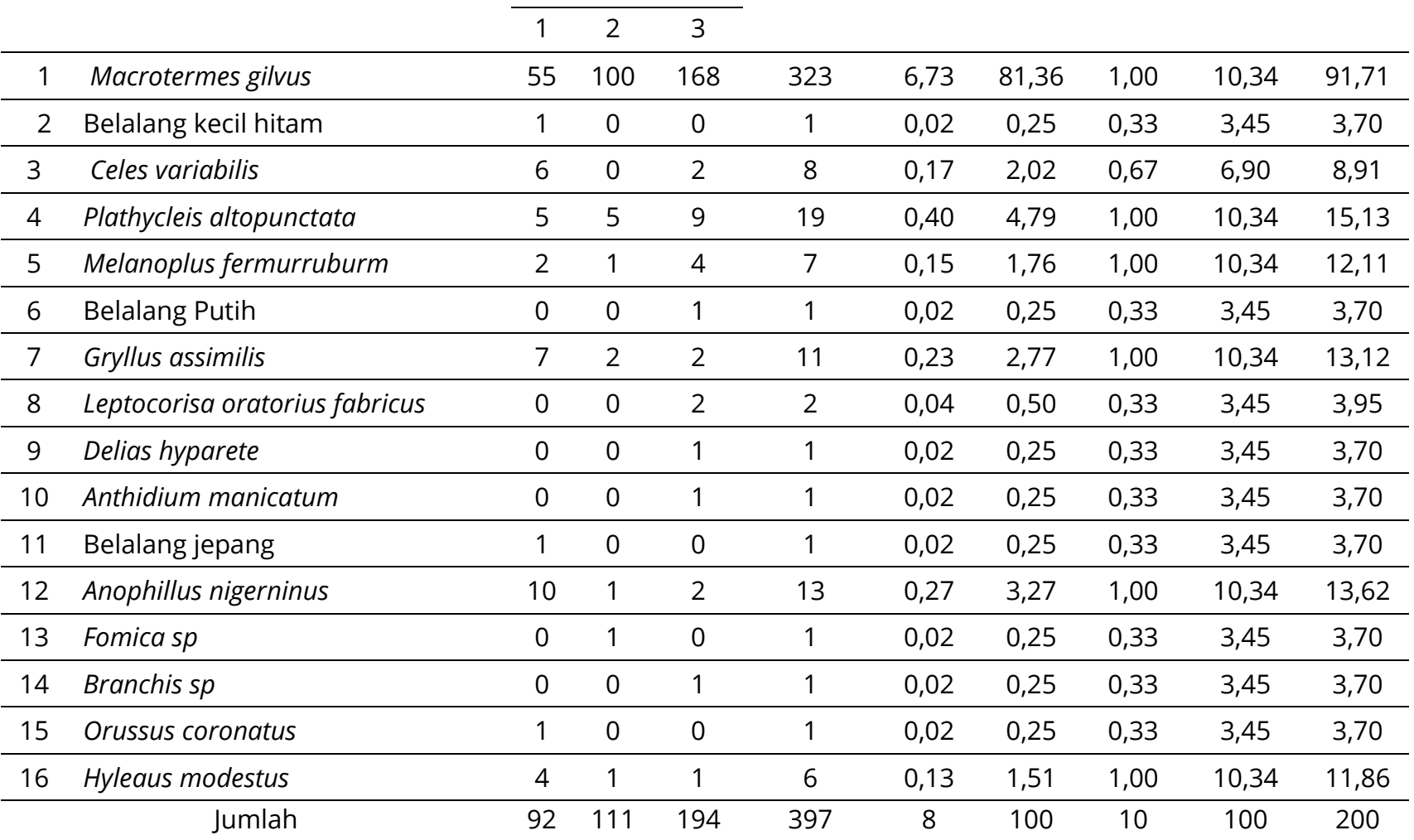

Dari data tabel 2 pada jalur 2 tegakan karet, didapat 17 jenis serangga dari perlakuan mulai dari sweep net (pagi dan sore), fit fall trap dan light trap dengan jumlah total individu sebanyak 397. Dengan demikian dapat diketahui bahwa nilai Kerapatan Mutlask (KM) tertinggi adalah kelompok laron sebanyak 6,73 dengan nilai Kerapatan Relatif (KR) sebesar 81,36\%, sedangkan Kerapatan Mutlak (KM) terendah adalah. Belalang kecil hitam, belalang putih, Delias hyparete, Anthidium manicatum, belalang jepang, Fonica sp, Branchis sp, Orussus coronatus. Sebesar 0,02 dengan kerapatan Relatif (KR) sebesar 0,25\%. Nilai Frekuensi Mutlak (FM) tertinggi adalah kelompok Macrotermes gilvus (laron), Platycleis altopunctata, Melanoplus fermurruburm, Gryllus assimilis, Anophilus nigerninus, Hyleaus modestus masing-masing sebesar 1, dengan Frekuensi Relatif (FR) sebesar 10,34\% sedangkan Nilai Frekuensi Mutlak (FM) terendah terdapat pada populasi belalang kecil hitam, belalang putih, Oratorius fabricus, Delias hyparete, Anthidium manicatum, belalang jepang, Fomica sp,Branchis sp,Orussus coronatus masing-masing sebesar 0,33 dengan Frekuensi Relatif (FR) sebesar 3,45 \%. Adapun Indeks Nilai Penting (INP) tertinggi terdapat pada populasi Laron dengan Nilai 91,71, sedangkan Indeks Nilai Penting (INP) terendah terdapat pada populasi Belalang kecil hitam, Belalng putih, Delias hyparete, Anthidium manicatum, Belalang jepang, Fomica sp, Branchis sp, Orussus coronatus. Untuk Indeks Nilai Penting (INP) yang diperoleh pada masing-masing populasi 
serangga dapat dilihat pada gambar 2

berikut.

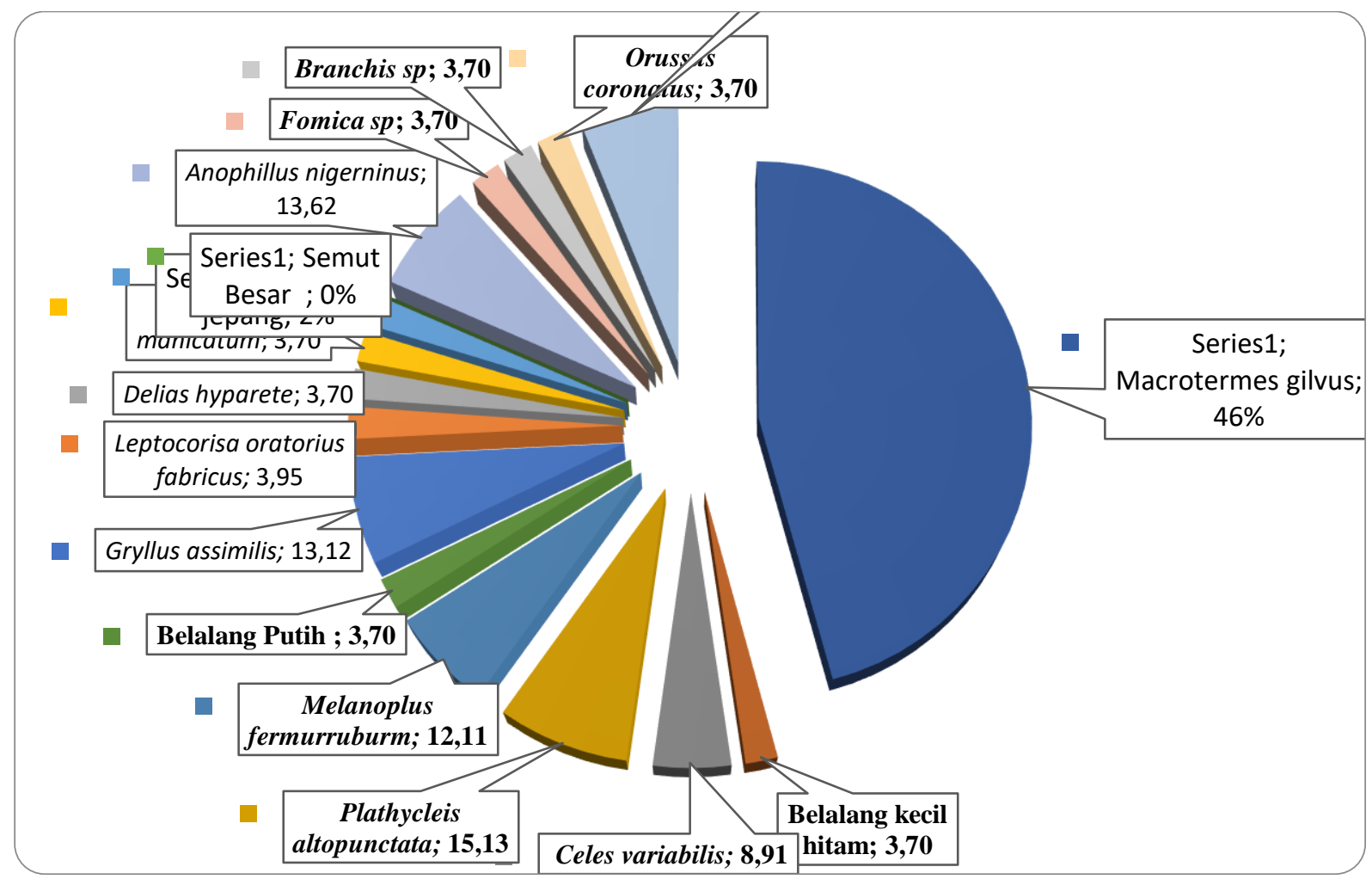

Gambar 2. Indeks Nilai Penting (INP) masing-masing serangga jalur II Tegakan Karet

Jalur III pada pengambilan sampel III didapati 14 jenis serangga. Pengamatan serangga didominasi pada tegakan pohon cokelat. Dari data yang diperoleh pada jalur hasil penangkapan serangga yang tertangkap dapat dilihat pada tabel berikut.

Tabel 3. Jumlah Serangga yang Tertangkap pada Jalur III (Tegakan Pohon Cokelat) dengan Indeks Nilai Penting (INP)

\begin{tabular}{|c|c|c|c|c|c|c|c|c|c|c|}
\hline \multirow{2}{*}{ No } & \multirow{2}{*}{ Nama Insekta } & \multicolumn{3}{|c|}{ Jumlah } & \multirow{2}{*}{$\begin{array}{c}\text { Jumlah } \\
\text { Total }\end{array}$} & \multirow{2}{*}{$\mathrm{KM}$} & \multirow{2}{*}{ KR \% } & \multirow{2}{*}{ FM } & \multirow{2}{*}{ FR (\%) } & \multirow{2}{*}{ INP } \\
\hline & & 1 & 2 & 3 & & & & & & \\
\hline 1 & Macrotermes gilvus & 44 & 110 & 23 & 177 & 3,69 & 72,54 & 1,00 & 15,00 & 87,54 \\
\hline 2 & Anthocaccus coccineus & 0 & 0 & 1 & 1 & 0,02 & 0,41 & 0,33 & 5,00 & 5,41 \\
\hline 3 & Celes variabilis & 3 & 0 & 0 & 3 & 0,06 & 1,23 & 0,33 & 5,00 & 6,23 \\
\hline 4 & Plathycleis altopunctata & 0 & 0 & 1 & 1 & 0,02 & 0,41 & 0,33 & 5,00 & 5,41 \\
\hline 5 & Cucujus cinnebarius & 0 & 2 & 0 & 2 & 0,04 & 0,82 & 0,33 & 5,00 & 5,82 \\
\hline 6 & Hister unicolor & 0 & 0 & 1 & 1 & 0,02 & 0,41 & 0,33 & 5,00 & 5,41 \\
\hline 7 & Gryllus assimilis & 3 & 0 & 6 & 9 & 0,19 & 3,69 & 0,67 & 10,00 & 13,69 \\
\hline 8 & Asiatic rhinoceros beetle & 0 & 0 & 1 & 1 & 0,02 & 0,41 & 0,33 & 5,00 & 5,41 \\
\hline 9 & Kupu-kupu malam & 8 & 0 & 0 & 8 & 0,17 & 3,28 & 0,33 & 5,00 & 8,28 \\
\hline 10 & Hylleus modestus & 0 & 1 & 0 & 1 & 0,02 & 0,41 & 0,33 & 5,00 & 5,41 \\
\hline 11 & Semut Besar & 4 & 0 & 2 & 6 & 0,13 & 2,46 & 0,67 & 10,00 & 12,46 \\
\hline 12 & Anophillus nigerninus & 2 & 0 & 28 & 30 & 0,63 & 12,30 & 0,67 & 10,00 & 22,30 \\
\hline
\end{tabular}




\begin{tabular}{llccccccccc}
\hline 13 & Formica $s p$ & 0 & 1 & 0 & 1 & 0,02 & 0,41 & 0,33 & 5,00 & 5,41 \\
\hline 14 & Lalat Hutan & 2 & 0 & 1 & 3 & 0,06 & 1,23 & 0,67 & 10,00 & 11,23 \\
\hline & 66 & 114 & 64 & 244 & 5,08 & 100,00 & 6,67 & 100,00 & 200,00 \\
\hline
\end{tabular}

Dari data tabel 3 di atas, dapat diketahui bahwa jumlah kelompok serangga yang diperoleh yaitu 14 jenis dengan perlakuan yang sama seperti dengan perlakuan penangkapan di Jalur II dan jalur I. Jumlah total serangga yang diperoleh pada jalur III sebanyak 244 individu. Dari tabel di atas dapat diketahui bahwa nilai Kerapatan Mutlak (KM) tertinggi adalah kelompok Laron (Macrotermes gilvus) yaitu sebanyak 3,69 dengan nilai Kerapatan Relatif (KR) tertinggi sebesar 72,54\% sedangkan Kerapatan Mutlak (KM) terendah adalah kelompok Anthocaccus coccineus, Plathyclleis altopunctata, Hister unicolor, Asiatic rhinoceros beetle, Hylleus modestus, dan Formica sp. yaitu sebanyak 0,02 dengan nilai Kerapatan Relatif (KR) terendah sebesar 0,41\%. Nilai Frekuensi Mutlak (FM) tertinggi adalah kelompok tertinggi adalah kelompok Laron (Macrotermes gilvus) yaitu sebanyak 1 dengan nilai Frekuensi Relatif (FR) tertinggi sebesar 15\% sedangkan Frekuens Mutlak (FM) terendah adalah kelompok Anthocaccus coccineus, Plathyclleis altopunctata, Hister unicolor, Asiatic rhinoceros beetle, Hylleus modestus, dan Formica sp. yaitu sebanyak 0,33 dengan nilai Frekuensi Relatif (FR) terendah sebesar 5\%. Indeks Nilai penting (INP) tertinggi diperoleh oleh kelompok tertinggi adalah kelompok Laron (Macrotermes gilvus) dengan INP sebesar 87,54 sedangkan Indeks Nilai Penting (INP) terendah adalah kelompok Anthocaccus coccineus, Plathyclleis altopunctata, Hister unicolor, Asiatic rhinoceros beetle, Hylleus modestus, dan Formica $s p$. yaitu sebanyak 0,02 dengan INP sebesar 5,41. Untuk nilai Indeks Penting (INP) yang diperoleh masing-masing jenis serangga dapat dilihat pada gambar 3 . di bawah ini.

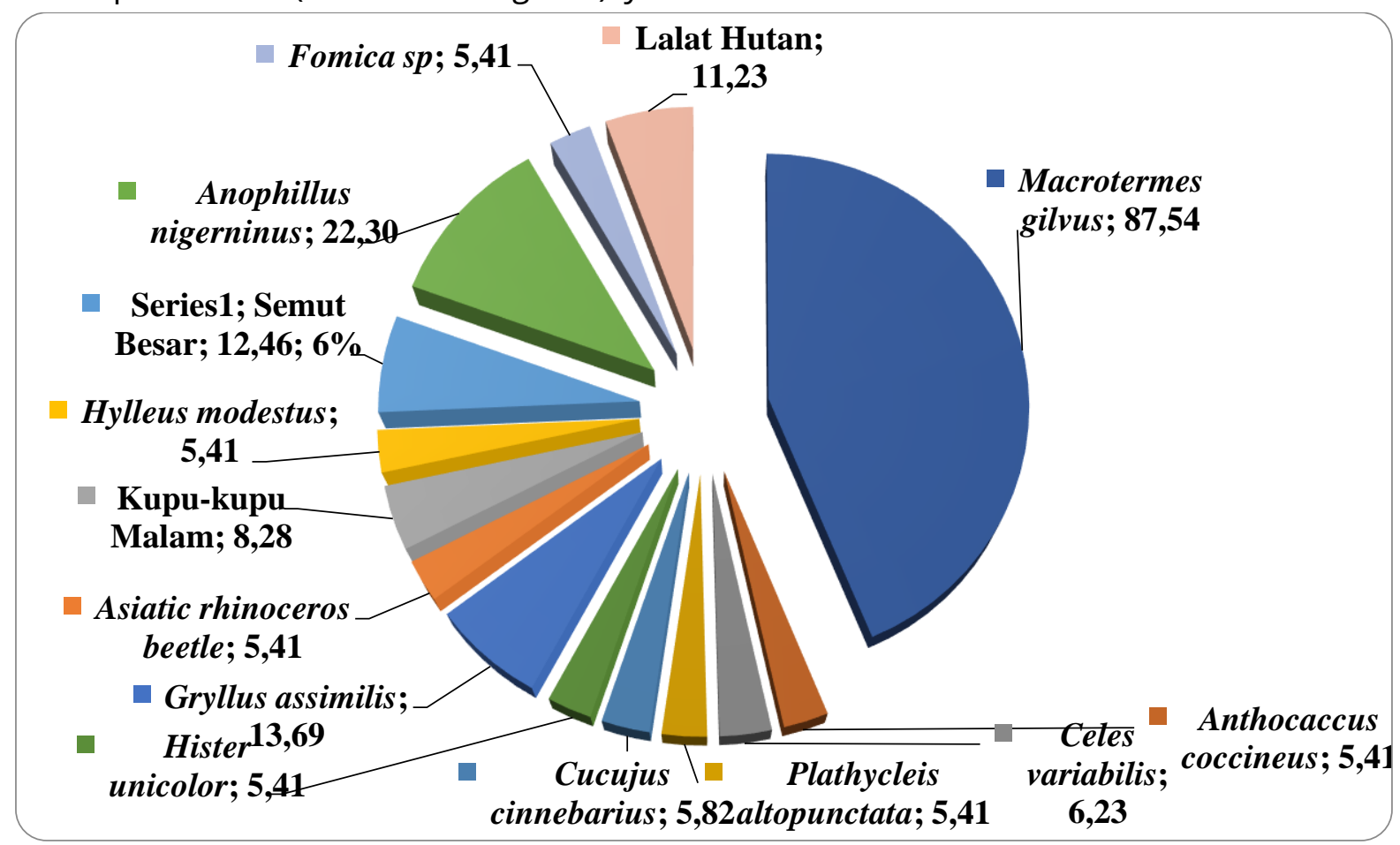

Gambar 3. Indeks Nilai Penting (INP) masing-masing serangga pada Jalur III (Tegakan Pohon Cokelat) 
Dari tabel 1 sampai tabel 3 dapat diketahui bahwa serangga yang tertangkap atau terjebak tidak selalu sama pada masing-masing jalur (Jalur I, Jalur II, dan Jalur III) di kawasan hutan penyangga. Ada beberapa serangga yang dominan dan ditemukan pada ketiga jalur di kawasan hutan penyangga dan sebaliknya. Selain itu, dari hasil penangkapan juga dapat diketahui bahwa terdapat jenis serangga yang hanya ditemukan pada jalur tertentu dengan petak contoh yang tertentu pula. Berdasarkan diagram Indeks Nilai Penting
(INP) pada masing-masing jalur, dapat pula diketahui bahwa kelompok Laron (Macrotermes gilvus) merupakan serangga yang memiliki Indeks Nilai Penting (INP) tertinggi diantara serangga lain pada kawasan hutan penyanggka Bukit Lawang.

Untuk mendapat indeks keanekaragaman serangga dari jalur I (tanpa tegakan) maka digunakan Indeks Keanekaragaman Serangga (Indeks Shannon-Wiener) dari 12 spesies yang di dapat. Lebih jelasnya pada tabel 4 di bawah ini.

Tabel 4. Indeks Keanekaragaman Serangga (Indeks Shannon-Wiener) Jalur I

\begin{tabular}{clcccc}
\hline & & \multicolumn{4}{c}{ Tanpa Tegakan (jalur 1) } \\
\cline { 3 - 6 } No & & $\mathrm{N}$ & $\mathrm{Pi}$ & $\mathrm{InPi}$ & $\mathrm{Pix} \mathrm{InPi}$ \\
\hline 1 & Macrotermes gilvus & 112 & 0,42 & $-0,86$ & $-0,36$ \\
\hline 2 & Semut hitam kecil & 15 & 0,06 & $-2,87$ & $-0,16$ \\
\hline 3 & Semut Hitam besar & 1 & 0,00 & $-5,58$ & $-0,02$ \\
\hline 4 & Celes variabilis & 1 & 0,00 & $-5,58$ & $-0,02$ \\
\hline 5 & Anophius nigerninus & 18 & 0,07 & $-2,69$ & $-0,18$ \\
\hline 6 & Semut Merah Bersayap & 27 & 0,10 & $-2,28$ & $-0,23$ \\
\hline 7 & Formica sp & 34 & 0,13 & $-2,05$ & $-0,26$ \\
\hline 8 & Gryllus assimilis & 35 & 0,13 & $-2,02$ & $-0,27$ \\
\hline 9 & Belalang kerdil hijau & 6 & 0,02 & $-3,78$ & $-0,09$ \\
\hline 10 & Belalang kayu & 13 & 0,05 & $-3,01$ & $-0,15$ \\
\hline 11 & Olibrus liquidus & 1 & 0,00 & $-5,58$ & $-0,02$ \\
\hline 12 & Blaberidae sp & 1 & 0,00 & $-5,58$ & $-0,02$ \\
\hline & & 264 & 1 & -42 & -2 \\
\hline & Jumlah & & & 2 & \\
\hline
\end{tabular}

Dari data hasil yang didapat berdasarkan Indeks Keanekaragaman Serangga (Indeks Shannon-Wiener) pada jalur I (tanpa tegakan) $\mathrm{H}^{\prime}=2$ (sedang). Jadi indeks keanekaragaman pada tanpa tegakan tergolong "sedang"
Setelah

mendapat

indeks keanekaragaman serangga dari jalur II (tegakan karet) maka digunakan Indeks Keanekaragaman Serangga (Indeks Shannon-Wiener) dari 16 spesies yang di dapat. Lebih jelasnya pada tabel 5 di bawah ini.

Tabel 5. Indeks Keanekaragaman Serangga (Indeks Shannon-Wiener) Jalur II

\begin{tabular}{llllll}
\hline & & \multicolumn{4}{c}{ Tegakan Karet (Tegakan 2) } \\
\cline { 2 - 5 } No & Spesies & $\mathrm{n}$ & $\mathrm{Pi}$ & $\ln \mathrm{Pi}$ & $\mathrm{Pix} \ln \mathrm{Pi}$ \\
\hline
\end{tabular}




\begin{tabular}{|c|c|c|c|c|c|}
\hline 1 & Macrotermes gilvus & 323 & 0,81 & $-0,21$ & $-0,17$ \\
\hline 2 & Belalang kecil hitam & 1 & 0,00 & $-5,98$ & $-0,02$ \\
\hline 3 & Celes variabilis & 8 & 0,02 & $-3,90$ & $-0,08$ \\
\hline 4 & Plathycleis altopunctata & 19 & 0,05 & $-3,04$ & $-0,15$ \\
\hline 5 & Melanoplus fermurruburm & 7 & 0,02 & $-4,04$ & $-0,07$ \\
\hline 6 & Belalang Putih & 1 & 0,00 & $-5,98$ & $-0,02$ \\
\hline 7 & Gryllus assimilis & 11 & 0,03 & $-3,59$ & $-0,10$ \\
\hline 8 & Leptocorisa oratorius fabricus & 2 & 0,01 & $-5,29$ & $-0,03$ \\
\hline 9 & Delias hyparete & 1 & 0,00 & $-5,98$ & $-0,02$ \\
\hline 10 & Anthidium manicatum & 1 & 0,00 & $-5,98$ & $-0,02$ \\
\hline 11 & Belalang jepang & 1 & 0,00 & $-5,98$ & $-0,02$ \\
\hline 12 & Anophillus nigerninus & 13 & 0,03 & $-3,42$ & $-0,11$ \\
\hline 13 & Fomica sp & 1 & 0,00 & $-5,98$ & $-0,02$ \\
\hline 14 & Branchis $s p$ & 1 & 0,00 & $-5,98$ & $-0,02$ \\
\hline 15 & Orussus coronatus & 1 & 0,00 & $-5,98$ & $-0,02$ \\
\hline 16 & Hyleaus modestus & 6 & 0,02 & $-4,19$ & $-0,06$ \\
\hline & Jumlah & 397 & 1 & -76 & -1 \\
\hline & $\mathrm{H}^{\prime}$ & \multicolumn{4}{|c|}{1} \\
\hline
\end{tabular}

Dari data hasil yang didapat berdasarkan Indeks Keanekaragaman Serangga (Indeks Shannon-Wiener) pada jalur II tegakan karet $\mathrm{H}^{\prime}=1$ (sedang). Jadi indeks keaneragaman pada tanpa tegakan tergolong "sedang" Setelah mendapat

Tabel 6. Indeks Keanekaragaman Serangga (Indeks Shannon-Wiener) Jalur III

\begin{tabular}{|c|c|c|c|c|c|}
\hline \multirow[b]{2}{*}{ No } & \multirow[b]{2}{*}{ Spesies } & \multicolumn{4}{|c|}{ Tegakan Coklat (Tegakan 3) } \\
\hline & & N & $\mathrm{Pi}$ & $\ln \mathrm{Pi}$ & $\mathrm{Pix} \ln \mathrm{Pi}$ \\
\hline 1 & Macrotermes gilvus & 177 & 0,73 & $-0,32$ & $-0,23$ \\
\hline 2 & Anthocaccus coccineus & 1 & 0,00 & $-5,50$ & $-0,02$ \\
\hline 3 & Celes variabilis & 3 & 0,01 & $-4,40$ & $-0,05$ \\
\hline 4 & Plathycleis altopunctata & 1 & 0,00 & $-5,50$ & $-0,02$ \\
\hline 5 & Cucujus cinnebarius & 2 & 0,01 & $-4,80$ & $-0,04$ \\
\hline 6 & Hister unicolor & 1 & 0,00 & $-5,50$ & $-0,02$ \\
\hline 7 & Gryllus assimilis & 9 & 0,04 & $-3,30$ & $-0,12$ \\
\hline 8 & Asiatic rhinoceros beetle & 1 & 0,00 & $-5,50$ & $-0,02$ \\
\hline 9 & Kupu-kupu malam & 8 & 0,03 & $-3,42$ & $-0,11$ \\
\hline 10 & Hylleus modestus & 1 & 0,00 & $-5,50$ & $-0,02$ \\
\hline 11 & Semut Besar & 6 & 0,02 & $-3,71$ & $-0,09$ \\
\hline 12 & Anophillus nigerninus & 30 & 0,12 & $-2,10$ & $-0,26$ \\
\hline 13 & Formica $s p$ & 1 & 0,00 & $-5,50$ & $-0,02$ \\
\hline 14 & Lalat Hutan & 3 & 0,01 & $-4,40$ & $-0,05$ \\
\hline & Jumlah & 244 & 1 & -59 & -1 \\
\hline & $\mathrm{H}^{\prime}$ & & & & \\
\hline
\end{tabular}

indeks keanekaragaman serangga dari jalur 2 (tegakan karet) maka digunakan Indeks Keanekaragaman Serangga (Indeks Shannon-Wiener) dari 14 spesies yang di dapat. Lebih jelasnya pada tabel 6 berikut. 
Dari data hasil yang didapat berdasarkan Indeks Keanekaragaman Serangga (Indeks Shannon-Wiener) pada jalur III tegakan cokelat $\mathrm{H}^{\prime}=1$ (sedang). Jadi indeks keaneragaman pada tanpa tegakan tergolong "sedang". Pada percobaan ini dilakukan analisis terhadap indeks keanekaragaman serangga dalam sebuah ekositem hutan penyangga dengan 3 jalur yaitu Jalur I (tanpa tegakan), Jalur II (tegakan pohon karet) dan jalur III (tegakan cokelat) masing-masing dengan 3 petak contoh untuk mengetahui tingkat keanekaragaman serangga di kawasan tersebut.

Pada percobaan ini dilakukan penangkapan serangga dengan menggunakan metode pengambilan sampel yaitu Fit Fall Trap, Light Trap, dan Sweeping net. Fit Fall Trap dibuat dengan menanamkan ember kedalam tanah dengan maksud sebagai jebakan serangga tanah. Sweeping net dilakukan dengan cara mengayunkan jebakan net sebanyak tiga kali putaran yang dilakukan pada 2 waktu yaitu pagi dan sore hari. Light Trap dibuat sebagai jebakan untuk serangga malam yang cenderung mendekati cahaya.

Dari hasil penangkapan dapat diketahui bahwa kelompok Laron (Macrotermes gilvus) merupakan kelompok serangga yang mendominasi pada kawasan hutan penyangga baik pada jalur I, Jalur II maupun Jalur III. Masing-masing petak contoh pada setiap jalur yang diberi perlakuan jebakan Light Trap hampir seluruhnya mendapati Laron (Macrotermes gilvus) sebagai serangga yang didapat dengan jumlah individu mencapai ratusan. Hal ini dikarenakan, Laron (Macrotermes gilvus) merupakan serangga yang cenderung menyukai cahaya dimana pada perlakuan jebakan "Light Trap" yang dibuat dikawasan hutan penyangga memiliki dukungan hidup lebih banyak dalam artian walaupun cahaya yang digunakan dalam jebakan dengan intensitas yang relatif rendah namun ketertarikan Laron (Macrotermes gilvus) terhadap cahaya sangat tinggi dikarenakan kawasan hutan terbiasa dalam keadaan tanpa cahaya (gelap) selain itu kondisi lingkungan di daerah hutan bukit lawang dalam kondisi musim penghujan (hutan dalam keadaan lembab). Hal ini mendukung keberadaan rayap ditemukan dalam jumlah yang banyak.

Dari hasil yang diperoleh dimana menunjukkan bahwa pada ketiga jalur tersebut memiliki keanekaragaman serangganya yang hampir sama dengan jumlah total individu yang tidak jauh berbeda. Namun, kebenaran data ini masih belum akurat diakibatkan karena beberapa faktor, diantaranya waktu pengambilan sampel dan cara pengambilan sampel. Faktor waktu yang dimaksud adalah pengambilan sampel dilakukan saat matahari hampir terbenam jadi sebagian serangga telah terbang maupun yang terjebak didalam jabakan tanah belum bisa mewakili tingkat keanekaragaman dari tempat tersebut. Selanjutnya dari cara pengambilan sampel, yang mana sewaktu pengambilan sampel, contohnya pada pengayunan sweeping net kebanyakan berada pada bagian atas rumput sehingga serangga atau sampel yang masuk ke dalam sweeping net adalah serangga yang terbang sehingga sampel tersebut belum bisa mewakili keanekaragaman tempat tersebut. Selain itu jumlah spesimen yang 
sedikit belum bisa mewakili dari tingkat keanekaragaman tempat tersebut.

Untuk Indeks Keanekaragaman serangga menurut Shannon-Wiener pada masing-masing jalur di kawasan hutan penyangga dapat dilihat dari tabel 7 di bawah ini.

Tabel 7 Perbandingan Indeks Keanekaragaman Serangga di Hutan Penyangga

\begin{tabular}{llcl}
\hline No & \multicolumn{1}{c}{ Lokasi } & Indeks Keanekaragaman & Keterangan \\
\hline 1 & Tanpa Tegakan & 2 & Sedang \\
\hline 2 & Tegakan Karet & 1 & Sedang \\
\hline 3 & Tegakan Cokelat & 1 & Sedang \\
\hline
\end{tabular}

Dari tabel 7 dapat diketahui bahwa jalur I (tanpa tegakan) memiliki Indeks keragaman $\left(\mathrm{H}^{\prime}\right)$ sebesar 2 (dua), jalur II (tegakan karet) memiliki Indeks Keragaman $\left(\mathrm{H}^{\prime}\right)$ sebesar 1 (satu) sedangkan pada jalur III (tegakan cokelat) memiliki Indeks Keragaman $\left(\mathrm{H}^{\prime}\right)$ sebesar 1 (satu). Ketiga nilai Indeks Keanekaragaman tersebut samasama dikategorikan sedang. Jadi dapat dikatakan bahwa Indeks Keanekaragaman serangga menurut Shannon-Wiener di kawasan hutan penyangga Bukit Lawang menunjukkan tingkat keanekaragaman yang sama yaitu sedang. Sehingga, dari tabel di atas dapat diketahui bahwa tidak ada perbandingan Indeks Keanekaragaman serangga menurut Shannon-Wiener di ketiga jalur kawasan Hutan Penyangga. Dengan kata lain hipotesis yang diambil dalam penelitian "tidak diterima".

Adapun hal yang menjadi keterbatasan dalam penelitian ini adalah 1) tempat pengambilan sampel berada di kawasan hutan yang sama yaitu hutan penyangga Bukit Lawang; 2) daerah yang menjadi tempat pengambilan sampel memiliki kondisi lingkungan biotik (makanan yang homogen) sehingga terdapat serangga yang mempunyai sifat yang seragam; 3) Selain lingkungan biotik, lingkungan abiotik juga dapat dikatakan mempengaruhi keberadaan serangga, contohnya kelembaban udara yang mendukung keberadaan suatu serangga di kawasan hutan penyangga,.

\section{SIMPULAN}

Berdasarkan hasil-hasil temuan penelitian dan analisis yang telah dilakukan oleh peneliti, maka diperoleh simpulan, sebagai berikut: 1) bahwa serangga dengan indeks nilai penting (INP) paling tinggi dari ketiga jalur (tanpa tegakan, tegakan karet dan tegakan cokelat) adalah Macrotermes gilvus yaitu 91,71 (tegakan pohon karet), 87,54 (tegakan pohon cokelat) dan 57,42 (tanpa tegakan); 2) Indeks keanekaragaman serangga $\mathrm{H}^{\prime}$ yang menggunakan (Indeks Shannon-Wiener) dari ketiga jalur Tanpa tegakan (-2), tegakan karet (-1) dan tegakan cokelat $(-1)$ adalah "rendah".

\section{SARAN}

Berdasarkan simpulan yang telah dikemukakan, maka sebagai tindak lanjut dari penelitian ini disarankan beberapa hal sebagai berikut: 1) masyarakat terutama para peneliti di daerah Bukit Lawang agar melestarikan lingkungan; 2) dari indeks dan indeks nilai penting yang didapat kiranya bisa menjadi standar untuk peduli terhadap lingkungan. 
DAFTAR PUSTAKA

Eko Sujatmiko, (2014). Kamus IPS, Surakarta:

Aksara Sinergi Media Cetakan I, halaman 109

Hadi, M., Tarwotjo, U., Rahardian, R. (2009) . Biologi Insekta Entomologi. Yogyakarta: Graha IImu.

Kimball, J.W. (2002). Fisiologi Tumbuhan. Erlangga. Jakarta.

Nadiah, Rejeki, Mardiyani. (2011). "Daya Predasi Kumbang Coccinellidae sebagai
Predator Kutu pada Tanaman Kapas". BBP2TP Surabaya.

Patty, N. (2006). Keanekaragaman Jenis Capung (Odonat) di Situ Gintung Ciputat, Tangerang. Jakarta: Fakultas Sains dan Teknologi UIN Syarif Hidayatullah

Wahyu, Eko dkk. (2013). Identifikasi Beberapa Jenis Ngengat Jantan Genus Arctornis (Lepidoptera: Noctuoidea) Di Indonesia Berdasarkan Karakter Morfologi Dan Genitalia. Jurnal. 